\title{
DETERMINAN PRODUKSI BUDIDAYA IKAN MUJAIR DENGAN POLA KERAMBA JARING APUNG DI KECAMATAN \\ WARKUK RANAU SELATAN KABUPATEN OGAN KOMERING ULU SELATAN
}

\author{
Juwita $^{(1)}$, Fifian Permata Sari ${ }^{(2)}$ \\ Mahasiswa (S1) Program Studi Agribisnis, Fakultas Pertanian, Universitas Baturaja \\ Jl. Ratu Penghulu Karang Sari No, 02301, OKU, Sumatera Selatan \\ E-mail : Faperta.Unbara@yahoo.com
}

\begin{abstract}
Determinan produksi budidaya ikan mujair pola keramba jaring apung di Kecamatan Warkuk Ranau Selatan Kabupaten Ogan Komering Ulu Selatan. (Di Bimbing oleh Dr. Fifian Permatasari, S.P., M.Si dan Henny Rosmawati, S.P., M.Si).

Tujuan penelitian adalah 1) Menganalisis faktor-faktor yang mempengaruhi produksi budidaya ikan mujair dengan pola keramba jaring apung di Desa Kota Batu Kecamatan Warkuk Ranau Selatan Kabupaten Ogan Komering Ulu Sealatan 2) Menghitung berapa pendapatan budidaya ikan mujair dengan pola keramba jaring apung di Desa Kota Batu Kecamatan Warkuk Ranau Selatan Kabupaten Ogan Komering Ulu Selatan. Pemilihan lokasi dilakukan secara Purposive yaitu secara sengaja berdasarkan pertimbangan bahwa di Kecamatan Warkuk Ranau Selatan ada 3 desa yang sedang dalam tahap pengembangan usaha ikan mujair. Peneilitian ini dilaksanakan pada bulan November 2017.

Metode penelitian yang digunakan adalah metode survey. Metode penarikan contoh yang digunakan dalam penelitian ini adalah metode metode acak berlapis tak berimbang (Disproportionated Stratified Random Sampling). Metode pengumpulan data yang digunakan dalam penelitian ini terdiri dari data primer dan data sekunder. Metode pengolahan dan analisis data yang digunakan dalam penelitian ini adalah dengan menggunakan pendekatan model fungsi produksi bertipe cobb-douglas.

Berdasarkan hasil penelitian disimpulah bahwa 1) Faktor - faktor yang berpengaruh signifikan yaitu luas KJA, pakan, dan bibit terhadap produksi budidaya ikan mujair dan untuk tenaga kerja berpengaruh tidak signifikan terhadap produksi ikan mujair di Desa Kota Batu. 2) Besarnya Pendapatan rata - rata petani budidaya ikan mujair dengan pola keramba jaring apung adalah sebesar Rp.25.222.467/thn.

\section{PENDAHULUAN}

\section{A. LatarBelakang}

Sasaran utama pembangunan nasional adalah untuk mencapai struktur perekonomian yang seimbang, yaitu

struktur yang memiliki sektor industri yang kuat didorong oleh sektor pertanian yang maju dan tangguh. Sektor petanian merupakan salah satu sektor yang mempunyai pranan yang cukup strategis
\end{abstract}


dalam perekonomian nasional, antara lain sebagai penyedia bahan pangan, pembuka lapangan kerja, pemasok bahan baku industri, dan sebagai sumber devisa Negara. Selain itu pemerataan pembangunan dalam rangka mewujudkan kondisi perekonomian yang lebih mantap dan dinamis tidak terlepas dari peran sub sektor non pangan utama seperti prikanan (Natakesuma, 2016).

Subsektor pertanian yang cukup besar menyumbang PDB pertanian adalah subsektor perikanan. BPS 2014 menyatakan bahwa subsektor perikanan menyumbang sebesar $22,34 \%$ atau $\mathrm{Rp}$ 82,26 triliun dari PDB pertanian pada triwulan II 2014. Kondisi tersebut menempatkan subsektor perikanan berada pada urutan ke dua setelah subsektor tanaman bahan makanan.Tabel 1 menjelaskan bahwa PDB subsektor perikanan mengalami kenaikkan pada setiap triwulan. Kenaikkan terbesar terjadi pada triwulan II 2014 dari sebelumnya sebesar 21,55\% pada triwulan I 2014 menjadi 22,34\% pada tiwulan II 2014.Hal ini menjelaskan bahwa sektor perikanan cukup berperan dalam meningkatkan PDB sektor pertanian.

Subsektor perikanan merupakan salah satu sektor yang dapat menunjang pembangunan perekonomian.Subsektor perikanan memegang peranan sangat penting dalam pembangunan perekonomian nasional, dimana sumberdaya perikanan Indonesia merupakan aset pembangnan yang memiliki peluang besar untuk dijadikan salah satu sumber pertmbuhan ekonomi. Sumber daya perikanan yang dimiliki oleh Indonesia beragam dan berpotensi diantaranya perikanan hasil tangkap dan perikanan budidaya yang mengarah untuk kemajuan perekonomian Indonesia. Usaha pembesaran ikan termasuk dalam pengendalian pertumbuhan. Budidaya ikan bertujuan untuk memperoleh hasil yang lebih tinggi atau lebih banyak dan lebih baik dari pada bila ikan tersebut dibiarkan hidup secara alami sepenuhnya. Beberapa teknik dalam pembudidayaan ikan pun dikembangkan untuk meningkatakan efisiensi dan produktivitas lahan perikanan yang tersedia. Teknik - teknik pembudidayaan ikan yang dikenal di Indonesia antara lain pembudidayaan ikan di kolam air deras, kolam air tenang dan keramba (Fauziah, 2015).

Salah satu perikanan budidaya yang berkontribusi paling besar adalah budidaya air tawar.Produksi budidaya ikan air tawar mencapai 3,881.602 ton pada tahun 2014.Produksi ini tertinggi dibandingkan poduksi ke dua budidaya lainnya yaitu budidaya air payau dan budidaya air laut.Besarnya produksi budidaya air tawara ini dikarenakan pemeliharaannya yang cukup mudah, dapat dilakukan di daerah maupun, serta tidak dipengaruhi oleh kondisi cuaca (Direktorat Jendral Perikanan Budidaya, 2014).

Budidaya ikan air tawar adalah suatu usaha dalam memelihara dan merawat ikan air tawar yang dilakukan di berbagai tempat, seperti di kolam, sungai, rawa, danau, dan waduk mulai dari penebaran benih ikan hingga siap panen (Saputra, 2014).

Ikan mujair merupakan jenis ikan konsumsi air tawar.Bentuk badannya pipih dengan warna abu-abu, coklat, atau hitam.Ikan mujair berasal dari perairan Afrika dan untuk pertama kali di Indonesiaditemukan oleh bapak Mujair di muara sungai Serang, pantai selatan Blitar Jawa Timur padatahun 1939. Ikan mujair mempunyai toleransi yang tinggi terhadap kadar garam atau salinitas 
air.Petumbuhannya cepat, tapi setelah dewasa, percepatan pertumbuhannya menurun. Panjang total maksimum yang dapat dicapai ikan mujair adalah $40 \mathrm{~cm}$ (Anto, 2015).

Budidaya ikan air tawar dalam KJA merupakan metode akuakultur yang paling produktif saat ini. Hal tersebut dikarenakan beberapa faktor kelebihan dalam penerapan teknik KJA diantaranya padat penebaran benih yang tinggi, ketersediaan kuantitas air, tidak memerlukan pengolahan tanah, pengendalian gangguan predator relatif lebih mudah, pemanenan lebih mudah, dan dapat dipindahkan ke lokasi lain (Direktorat Jendral Perikanan Budidaya, 2009).

Budidaya ikan air tawar dengan pola keramba jaring apung(KJA) saat ini banyak ditemui di Kabupaten Ogan Komering UluSelatan.Kabupaten Ogan Komering Ulu Selatan memiliki beberapa danau salah satunya yaitu Danau Ranau sebagai pusat pembudidayaan ikan air tawar tepatnya di Kecamatan Warkuk Ranau Selatan yang merupakan daerah yang memiliki prospek yang cukup baik untuk pengembangan produksi ikan dengan polakeramba jaring apung (KJA), karena berada di sekitaran Danau Ranau.

Sumatera Selatan terpilih menjadi lokasi pusat pengembangan perikanan perairan umum di kawasan ASEAN seiring dukungan pemerintah provinsi itu dan potensi dan perikanan perairan mum yang dimiliki. Saat ini luasan perairan umum daratan mencapai 2,5 juta hektar, meliputi sungai musi beserta anak sungai, rawa dan danau. Untuk potensi produksi perikanan air tawar sendiri mencapai 51.952 ton dari total produsi perikanan Sumsel yang mencapai 525.679 ton per tahun (Mukti, 2013).

Data statistik 2015, Menunjukkan produksi ikan air tawar Kabupaten Ogan Komering Ulu Selatan adalah sebagai berikut:

Tabel 1. Produksi ikan air tawar di Kabupaten Ogan Komering Ulu Selatan

\begin{tabular}{|c|c|c|}
\hline Kecamatan & $\begin{array}{l}\text { Produksi } \\
\text { (Ton) }\end{array}$ & $\begin{array}{c}\text { Nilai } \\
\text { (Rp.000) }\end{array}$ \\
\hline Mekakau Ilir & 14.776 & 79.104 \\
\hline Banding & 79.104 & 79.104 \\
\hline Agung & & \\
\hline $\begin{array}{l}\text { BPR. Ranau } \\
\text { Tengah }\end{array}$ & 27.520 & 27.520 \\
\hline $\begin{array}{l}\text { Warkuk } \\
\text { Ranau } \\
\text { Selatan }\end{array}$ & 93.580 & 93.580 \\
\hline Buay Pemaca & 22.800 & 22.800 \\
\hline Simpang & 8.390 & 8.390 \\
\hline Muaradua & 59.112 & 59.112 \\
\hline Buay Rawan & 20.310 & 20.310 \\
\hline Buay & 27.430 & 27.430 \\
\hline Sandang Aji & & \\
\hline Tiga Dihaji & 23.000 & 23.000 \\
\hline Buay & 23.380 & 23.380 \\
\hline Runjung & & \\
\hline Runjung & 21.640 & 21.640 \\
\hline Agung & & \\
\hline Kisam Tinggi & 18.280 & 18.280 \\
\hline Muaradua & 13.230 & 13.230 \\
\hline Kisam & & \\
\hline Kisam Ilir & 28.260 & 28.260 \\
\hline Pulau & 32.366 & 32.366 \\
\hline Beringin & & \\
\hline Sindang & 27.800 & 27.800 \\
\hline Danau & & \\
\hline Sungai Are & 14.500 & 14.500 \\
\hline Buana & 14.500 & 14.500 \\
\hline Pemaca & & \\
\hline Jumlah & 565.918 & 565.918 \\
\hline $\begin{array}{cc}\text { Sumber : } & \text { Dinas } \\
& \text { Ogan } \\
& 2015\end{array}$ & $\begin{array}{l}\text { Perikanan } \\
\text { Komering I }\end{array}$ & $\begin{array}{l}\text { Kabupaten } \\
\text { lu Selatan, }\end{array}$ \\
\hline
\end{tabular}


Tabel 1 menunjukkan produksi ikan air tawar tertinggi di Kabupaten Ogan Komering Ulu Selatan adalah di Kecamatan Warkuk Ranau Selatan dengan nilai produksi 565.918 ton/tahun.Hasil tersebut mayoritas berasal dari tambak ikan pola keramba jaring apung (KJA) di sepanjang Danau Ranau.

Desa Kota Batu adalah salah satu desa yang terdapat di Kecamatan Warkuk Ranau Selatan yang luas lahan perikanannya tergolong lebih luas dari luas lahan desa lainnya, yaitu sebesar 26,17 hektar dengan jumlah produksi sebesar $433.300 \mathrm{Kg} / \mathrm{thn}$. Hal tersebut dapat dilihat pada Tabel 3.

Tabel 2. Luas Keramba dan Produksi Ikan Budidaya KJA di Kecamatan Warkuk Ranau Selatan Tahun 2016

\begin{tabular}{llcc}
\hline No & $\begin{array}{l}\text { Desa/Kampu } \\
\text { ng }\end{array}$ & $\begin{array}{c}\text { Luas } \\
\text { Lahan } \\
\text { (ha) }\end{array}$ & $\begin{array}{c}\text { Produksi } \\
\text { (Kg/thn) }\end{array}$ \\
\hline 1 & Sukajaya & 0 & 0 \\
$\mathbf{2}$ & Kota Batu & $\mathbf{2 6 , 1 7}$ & $\mathbf{4 3 3 . 3 0 0}$ \\
3 & Pagar Dewa & 0 & 0 \\
4 & Tanjung Jati & 4,32 & 61.200 \\
5 & Gunung Aji & 0 & 0 \\
6 & Pilla & 0 & 0 \\
7 & Gunung Raya & 0 & 0 \\
8 & Remanam & 0 & 0 \\
& Jaya & & \\
9 & Bedeng Tiga & 0 & 0 \\
10 & Tanjung Baru & 0 & 0 \\
11 & Way Wangi & 5,28 & 601.900 \\
12 & Kiwis Raya & 0 & 0 \\
13 & Segigok Raya & 0 & 0 \\
14 & Bumi Agung & 0 & 0 \\
15 & Mekar Sari & 0 & 0 \\
16 & Gedung & 0 & 0 \\
& Ranau & & \\
\hline & Jumlah & $\mathbf{3 6 , 3 3}$ & $\mathbf{1 0 7 . 4 0 0}$ \\
\hline
\end{tabular}

Sumber: UPTD Perikanan Kecamatan Warkuk Ranau Selatan 2015.

Pola agribisnis ikan mujair dituntut untuk mempraktekkan teknik budidaya secara intensif. Budidaya (pemeliharaan) ikan mujair secara intensif ditandai antara lain dengan penerapan teknologi, terutama pemberian makanan buatan (pakan pelet) yang bergizi, lengkap dan seimbang untuk kehidupan dan pertumbuhan ikan. Peningkatan produksi yang tinggi banyak ditentukan oleh faktor pemberian pakan yang intensif, baik dari segi kualitas maupun kuantitas.Untuk kegiatan budidaya ikan mujair secara intensif dituntut persyaratan produksi yang sangat tinggi, salah satu di antaranya adalah padat penebaran ikan yang dipelihara cukuptinggi, sehingga tentunya diperlukan pakan dalam jumlah yang tinggi pula (Rukmana, 2003).

Faktor produksi mempengaruhi jumlah produksi yang akan dihasilkan dalam suatu usahatani. Penggunaan faktorproduksi perlu diperhatikan dalam kegiatan usahatani agar tidak terjadi penggunaan yang berlebihan yang dapat merugikan petani ikan mujair atau mempengaruhi pendapatan dan menyebabkan tingkat produksi yang tidak optimal. Dan kendala yang umumnya dihadapi para petani adalah bagaimana mengalokasikan faktor-faktor produksi tersebut untuk mendapatkan produksi ikan mujair di Desa Kota Batu belum optimal, sehingga berdampak pada hasil produksi ikan mujair.Oleh karena itu untuk mengantisipasi faktor-faktor produksi, untuk mencapai hasil produksi yang optimal (Zahara, 2013).

Berdasarkan latar belakang tersebut maka penulis tertarik untuk mengkaji lebihlajut mengenai "Determinan produksi ikan mujair di Desa Kota Batu Kecamatan 
Warkuk Ranau Selatan Kabupaten Ogan Komering Ulu Selatan”.

\section{B. Rumusan Masalah}

Berdasarkan pada dasar latarbelakang yang telah di jelaskan makapermasalahan yang menarik untuk diangkat dalam penelitian ini adalah :

1. Faktor-faktor apa saja yang mempengaruhi produksi budidaya ikan mujair dengan pola keramba jaring apung di Desa Kota Batu Kecamatan Warkuk Ranau Selatan Kabupaten Ogan Komering Ulu Selatan?

2. Berapa besar pendapatan budidaya ikan mujair dengan pola keramba jaring apung di Desa Kota Batu Kecamatan Warkuk Ranau Selatan Kabupaten Ogan Komering Ulu Selatan ?

\section{Tujuan Penelitian}

Berdasarkan latar belakang dan rumusan masalah di atas, maka tujuan penelitian ini adalah :

1. Menganalisis faktor-faktor yang mempengaruhi produksibudidaya ikan mujair dengan pola keramba jaring apung di Desa Kota Batu Kecamatan Warkuk Ranau Selatan Kabupaten Ogan Komering Ulu Sealatan.

2. Menghitung berapa pendapatan budidayaikan mujair dengan pola keramba jaring apung di Desa Kota Batu Kecamatan Warkuk Ranau Selatan Kabupaten Ogan Komering Ulu Selatan

\section{Kegunaan Penelitian}

Hasil penelitian yang dilakukan juga diharapkan dapat berguna bagi pihakpihak terkait seperti dalam hal dibawah ini

1. Bagi pembudidaya ikan mujair dengan pola keramba jaring apung, dari hasil penelitian ini diharapkan dapat dijadikan sebagai salah satu rekomendasi untuk pengambilan keputusan dalam mengembangkan usaha yang sedang dijalankan, terutama dalam mengalokasikan faktor - faktor produksi dalam budidaya ikan mujair dengan pola keramba jaring apung.

2. Bagi penulis, dari hasil penelitian ini diharapkan bagi peneliti menambah khasanah ilmu pengetahuan terutama mengenai masalah faktor - faktor yang mempengaruhi produksi pembudidayaan ikan mujair dengan pola keramba jaring apung.

3. Bagi universitas, dari hasil penelitian ini diharapkan bagi universitas dapat dijadikan sebagai referensi dan masukan bagi peneliti masa mendatang dalam mengkaji masalah faktor - faktor produksi terhadap budidaya ikan mujair dengan pola keramba jaring apung.

\section{METODELOGI PENELITIAN}

\section{A. Ruang Lingkup dan Waktu Penelitian}

Penelitian ini dilaksanakan di Desa Kota Batu Kecamatan Warkuk Ranau Selatan Kabupaten Ogan Komering Ulu Selatan, dimana penentuan daerah di lakukan secara sengaja(purposive). Mengingat dengan daerah ini banyak warga yang mengusahakanikan dengan pola keramba jaring apung. Pelaksanaan penelitian dilaksanakan pada bulan November tahun 2017.

\section{B. Metode Penelitian}

Metode yang digunakan dalam penelitian ini adalah metode survei, yaitu metode yang digunakan untuk memperoleh data-data atau fakta yang ada dan mencari keterangan secara faktual. Data diperoleh dengan cara mewawancara responden yang ada dalamsampel dengan menggunakan 
kuisioner sebagai alat pengumpulan data yang telah dipersiapkan sebelumny

\section{Metode Penarikan Contoh}

Metode penarikan contoh yang digunakan dalam penelitian ini adalah metode acak berlapis tak berimbang (Disproportionated Stratified Random Sampling). Adapun jumlah populasi Pengusaha ikan mujair keramba jaring apung di Desa Kota Batu Kecamatan Warkuk Ranau Selatan Kabupaten Ogan Komering Ulu Selatan adalah 59 orang dan diambil 30 sampel.

\section{Metode Pengumpulan Data}

Dalam penelitian ini data yang dikumpulkan meliputi data primer dan data skunder. Data rimer yaitu data yang diperoleh dari petani pembudidaya ikan dengan pola keramba jaring apung dengan metode wawancara. Data sekunder yaitu data yang diperoleh dari instansi-instansi yang terkait dalam penelitian ini.

\section{E. Metode Pengolahan dan Analisis Data}

Metode pengolahan data yang digunakan dalam penelitian ini adalah dengan analisis fungsi produksi bertipe cobb-douglas Untuk menjawab rumusan masalah yang pertama yaitu untukmengetahui faktor - faktor yang bberpengaruh terhadapbudidaya ikan mujair. Dan untuk menjawab rumusan masalah yang kedua yaitu dengan menggunakan Analisis pendapatan.

\section{HASIL DAN PEMBAHASAN}

\section{A. Identitas Petani Yang Melakukan}

\section{Usaha Ikan Mujair Pola Keramba}

1. Umur Petani Contoh

Berdasarkan hasil penelitian diketahui bahwa umur petani di Desa Kota
Batu diketahui umurnya berkisar 30 sampai 60 tahun. Secara keseluruhan petani contoh ikan mujair pola keramba jaring apung tergolong dalam penduduk usia produktif, baik dari segi fisik maupun kematangan berfikir

\section{Tingkat Pendidikan Petani Contoh}

Tingkat pendidikan petani juga merupakan aspek yang dapat mempengaruhi kegiatan budidaya ikan mujair. Hal ini disebabkan dengan tingkat pendidikan yang memadai dapat mengambil keputusan apabila dihadapkan dengan beberapa masalah yang berhubungan dengan kegiatan usaha yang dilakukan. Adapun sebaran tingkat pendidikan petani contoh ikan mujair dengan pola keramba jaring apung di desa Kota Batu Kecamatan Warkuk Ranau Selatan terdiri dari sekolah dasar (SD), sekolah menengah pertama (SMP) dan sekolah menengah atas (SMA).

Usaha ikan mujair harus dilakukan dengan teknik budidaya yang baik dan benar sehingga menghasilkan kualitas ikan yang baik. Oleh karena itu, pendidikan dan pengetahuan tentang usaha ikan mujair diperlukan agar dapat memudahkan petani dalam melakukan usaha ikan mujair.

\section{Jumlah Anggota Keluarga Petani Contoh}

Dari hasil penelitian diketahui bahwa jumlah keluarga dari masing-masing petani sampel di Desa Kota Batu sangatlah bervariasi yaitu berkisar antara 3 sampai 4 orang dengan rata - rata 4 orang perkeluarga.

hubungan antara jumlah anggota keluarga/tanggungan dengan usaha ikan mujair adalah selain teknik budidaya yang baik dan benar, keluarga juga dapat mempengaruhi keberhasilan suatu usaha. Semakin besar pendapatan usaha ikan 
$\begin{array}{lllllll}\text { mujair maka semakin besar pulaTenaga } & \text { Kerja } & -0.016 & -0,285 & 0.778\end{array}$ pengeluaran keluarga atau tanggungan $\left(\mathrm{X}_{4}\right)$

yang dikeluarkan. Petani contoh ikan $\overline{R^{2}}=0,975$

mujair memiliki tanggungan masing- $\overline{\mathrm{F}_{\text {hitung }}}=171.027$

masing sehingga petani ikan mujair Sumber: Data primer, 2017

memiliki pengluaran yang berbeda,

\section{Luas Keramba Petani Contoh}

Berdasarkan dari hasil penelitian diketahui luas kolam di Desa Kota Batu Kecamatan Warkuk Ranau Selatan Kabupaten Ogan Komering Ulu Selatan. Petani contoh yang membudidayakan Ikan mujair dengan pola KJA memiliki luas keramba sebesar 12 × $20 \mathrm{~m}, 15 \times 30 \mathrm{~m}$ dan $18 \times 30 \mathrm{~m}$

\section{Analisis Faktor - Faktor yang Mempengaruhi Produksi}

Faktor - faktor produksi yang diedintifikasikan dapat mempengaruhi produksi usahatani budidaya ikan mujair dengan pola KJA di Desa Kota Batu Kecamatan Warkuk Ranau Selatan Kabupaten Ogan Komering Ulu adalah luas KJA $\left(\mathrm{X}_{1}\right)$, pakan $\left(\mathrm{X}_{2}\right)$, Bibit $\left(\mathrm{X}_{3}\right)$, dan tenaga kerja $\left(\mathrm{X}_{4}\right)$. Untuk menganalisa pengaruh Faktor - faktor produksi terhadap produksi budidaya ikan mujair dengan pola keramba jaring apung digunakan fungsi Cobb-Douglass yang dipakai untuk mngestimasipengaruh faktor - faktor variabel independen (X) terhadap variabel dependen (Y). Hasil analisis regresi linier berganda dari fungsi produksi dapat dilihat pada Tabel 13 .

Tabel 13. Hasil Analisis Regresi Linier Berganda dengan Fungsi Cobb-Douglass.

\begin{tabular}{lcccc}
\hline \multicolumn{1}{c}{ Variabel } & $\begin{array}{c}\text { koefis } \\
\text { ien }\end{array}$ & thitung & $\begin{array}{c}\text { Proba } \\
\text { biliti }\end{array}$ & $\begin{array}{c}\text { Tar } \\
\text { af }\end{array}$ \\
\hline Intersep & 1.566 & 7.777 & 0.000 & \\
Luas Lahan $\left(\mathrm{X}_{1}\right)$ & 1.313 & 17.764 & 0.001 & $*$ \\
Pakan $\left(\mathrm{X}_{2}\right)$ & 1.491 & 13.268 & 0.001 & $*$ \\
Bibit $\left(\mathrm{X}_{3}\right)$ & 0.128 & 2.223 & 0.005 & $* *$ \\
\hline
\end{tabular}

Keterangan :

* : berpengaruh signifikan pada taraf uji $\alpha 0,001$

** : berpengaruh signifikan pada taraf uji $\alpha 0,005$

Dari hasil analisi data dengan menggunakan analisis regresi linier berganda dari fungsi cobb-douglass diperoleh persamaan estimasi dalam bentuk transformasi regresi linier sebagai berikut :

\section{$Y=1,566+1,313 X_{1}+1,491 X_{2}+0,128 X_{3}$ $-0,016 X_{4}$}

Dari hasil regresi linier berganda dengan fungsi produksi cobb-douglass diperoleh juga nilai koefisien determinasi $\left(\mathrm{R}^{2}\right)$ sebesar 0.975 menunjukkan bahwa sekitar 97,5\% variabel dependen (Y) dapat dijelaskan variabel luas KJA $\left(\mathrm{X}_{1}\right)$, pakan $\left(\mathrm{X}_{2}\right)$, bibit $\left(\mathrm{X}_{3}\right)$, dan tenaga kerja $\left(\mathrm{X}_{4}\right)$, sedangkan $25 \%$ dijelaskan oleh variabel lain yang tidak dimasukkan dalam model ini.

Dari hasiluji $F$ diperoleh $F_{\text {hitung }}$ sebesar 171,027 pada taraf signifikan 0,001 artinya secara persial variabel luas KJA $\left(\mathrm{X}_{1}\right)$, Pakan $\left(\mathrm{X}_{2}\right)$, Bibit $\left(\mathrm{X}_{3}\right)$, dan tenaga kerja $\left(\mathrm{X}_{4}\right)$ berpengaruh signifikan terhadap produksi budidaya ikan mujair.

Secara persial variabel yang luas KJA, pakan, dan bibit berpengaruh signifikan terhadap produksi budidaya ikan mujair pada taraf 0,01 terhadap produksi budidaya ikan mujair pada taraf 0,05 sedangkan tenaga kerja berpengaruh tidak signifikan terhadap budidaya ikan mujair. untuk lebih jelasnya pengaruh dari masing 
- masing variabel independen terhadap produksi budidaya ikan mujair dengan pola keramba jaring apung di Desa Kota Batu dapat di interprestasikan sebagai berikut.

\section{Luas Keramba Jaring Apung}

Faktor produksi luas keramba jarring apung berpengaruh signifikan pada taraf uji $\alpha$ 0,001terhadap produksi ikan mujair dengan koefisien regresi sebesar 1,313 Kg. Hal ini menunjukkan bahwa jikaluas keramba jaring apung ditambah 1 $\mathrm{m}^{2}$ maka akan semakin bertambah pula jumlah produksi ikan mujair sebesar 1,313 Kg. berdasarkan hasil uji $\mathrm{t}$ diketahui bahwa secara persial variabel luas KJA berpengaruh signifikan terhadap produksi ikan mujair. Artinya luas atau sempitnya KJA yang dimiliki oleh petani ikan akan berpengaruh terhadap tinggi rendahnya produksi ikan mujair. Hal ini senada dengan penelitian Arie (2015), yang menyatakan bahwa ada hubungannya antara luas keramba terhadap produksi ikan yaitu, dengan bertambah luasnya keramba yang di pakai maka jumlah produksinya pun akan meningkat.

\section{Pakan}

Faktor produksi pakan berpengaruh signifikan pada taraf uji $\alpha 0,001$ dengan koefisien regresiproduksi sebesar 1,491 Kg berarti setiap satu kilogram pakan pelet ikan akan meningkatkan produksi ikan mujair sebesar 1,49 Kg. Hal ini dikarenakan pakan merupakan sarana produksi yang digunakan harus diperhitungkan mutunya dan jumlah pemakaian agar mencapai efisiensi yang optimal bagi pertumbuhan ikan. hal ini senada dengan penelitian Achmad(2017), yang menyatakan bahwa pakan berpengaruh terhadap produksi ikan sehingga harus diperhatikan mutu dan jumlah pemakainnya agar penggunaan pakan dapat digunakan secara efisiensi sehingga pertumbuhan ikan terjadi secara optimal.

\section{Bibit}

Faktor produksi bibit ikan mujair berpengaruh signifikan pada taraf uji $\alpha$ 0,005 terhadap produksi budidaya ikan mujair dengan koefisien regresi sebesar $0,128 \mathrm{Kg}$ berarti setiap satu ekor input bibit dapat meningkatakan produksi sebesar 0,128 Kg. Hal ini berarti bahwa jumlah bibit ikan dapat meningkatkan jumlah produksi ikan mujair. Hal ini sependapat dengan Ardhya (2013), yang menyatakan bahwa ada hubungannya jumlah bibit terhadap produksi yaitu, jumlah bibit yang digunakan sesuai dengan luas keramba. Jika terlalu banyak bibit tidak sesuai dengan luas keramba akan menyebabkan peluang terjadinya kematian pada ikan, karena luas keramba mempengaruhi gerak ikan.

\section{Tenaga Kerja}

Faktor produksi tenaga kerja sebesar $-0,16$ berarti apabila tenaga kerja ditambah satu orang maka produksi akan menurun sebesar $0,16 \mathrm{Kg}$. Faktor produksi tenaga kerja berpengaruh tidak signifikan terhadap produksi budidaya ikan mujair. Hal ini menunjukkan bahwa penambahan tenaga kerja tidak akan berpengaruh terhadap peningkatan produksi. Hal ini senada dengan penelitian Nurul (2016), yang menyatakan bahwa tenaga kerja tidak selalu mempengaruhi produksi. Produksi secara nyata dipengaruhi oleh jumlah bibit dan pakan yang diberikan. Hal ini akan menyebakan pendapatan petani ikan menjadi berkurang. 


\section{Analisis Pendapatan Usahatani Budidaya Ikan Mujair Pola Keramba Jaring Apung}

\section{Biaya Produksi Budidaya Ikan Mujair}

Biaya produksi merupakan semua biaya yang harus dikeluarkan dalam melakukan usahatani budidaya ikan mujair yang terdiri dari biaya tetap dan biaya variabel. Biaya variabel pada sahatani budidaya ikan mujair di Desa Kota Batu adalah luas KJA, pakan, bibit, dan tenaga kerja.Sedangkan, biaya tetap adalah penyusustan alat - alat pertanian yang digunakan untuk budidaya ikan mujair Biaya tetap dan biaya variabel pada usahatani budidaya ikan mujair tersebut menghasilkan total biaya seperti yang dapat dilihat pada Tabel 14 dan lampiran 9.

Tabel 14.Rata - rata Biaya Produksi Budidaya Ikan Mujair Pola Keramba Jaring Apung di Desa Kota Batu

\begin{tabular}{lc}
\hline \multicolumn{1}{c}{ Uraian } & $\begin{array}{c}\text { Jumlah Biaya } \\
\text { (Rp/Tahun) }\end{array}$ \\
\hline 1. Biaya Tetap & \\
- Bambu & 65.000 \\
- Waring & 275.000 \\
- Balok Kayu & 325.500 \\
Total Biaya & 692.500 \\
Penyusutan & \\
2. Biaya Variabel & 2.857 .500 \\
-Bibit & 28.400 .000 \\
- Pakan & 46.600 \\
- Obat-obatan & 34.334 \\
- Tali & 26.600 \\
- Paku & 3.553 .334 \\
- Tenaga Kerja & \\
\hline Biaya Total & $\mathbf{3 5 . 6 1 0 . 8 6 8}$ \\
Produksi & \\
\hline Sumber :Data primer & \\
\hline
\end{tabular}

Sumber :Data primer yang diolah, 2017

Data Tabel 14, dapat dilihat bahwa rata - rata biaya produksi budidaya ikan mujair antara lain yaitu biaya penyusutan alat sebesar Rp. 692.500, biaya bibit sebesar R. 2.857.500, biaya pakan sebesar Rp. 28.400.000, biaya obat - obatan Rp. 46.600, biaya tali Rp. 34.334, biaya paku Rp. 26.600, biaya tenaga kerja sebesar Rp. 3.553.333. Jadi total biaya produksi yang dikeluarkan oleh petani budidaya ikan mujair yaitu sebesar Rp. 35.610.868.

\section{Produksi dan Penerimaan Budidaya Ikan Mujair dengan Pola Keramba Jaring Apung}

Produksi adalah hasil yang diperoleh petani ikanmujair pada saat panen. Setiap petani mengharapkan usaha budidaya ikan tersebut akan mendapatkan keuntungan yang besar, hal tersebut dilihat dari bagaimana peternak lebih meningkatkan pemerhatian terhadap budidaya tersebut. Harga yang diterima petani keseluruhan rata-rata Rp. $25.000 / \mathrm{kg}$. Penerimaan yang diperoleh petani dari produksi rata-rata $2.116 \mathrm{~kg} /$ tahun dan harga Rp. 25.000/kg adalah Rp. 60.833.334/tahun. Adapaun rincian penerimaan budidaya ikan mujair di Desa Kota Batu dapat disajikan pada Tabel 15 dan lampiran 10.

Tabel 15. Rata-rata Penerimaan dari Budidaya Ikan Mujair Pola Keramba Jaring Apung di Kecamatan Warkuk Ranau Selatan

\begin{tabular}{clc}
\hline No & \multicolumn{1}{c}{ Uraian } & Jumlah \\
\hline 1 & Produksi & 2.116 \\
2 & (Kg/Tahun) & \\
3 & Harga (Rp) & 25.000 \\
& Penerimaan & \\
& (Rp/Tahun) & 60.833 .334 \\
\hline
\end{tabular}

Sumber :Data primer yang diolah, 2017

Tabel 15, menunjukkan bahwa rata-rata produksi yang dihasilkan peternak 
ikan $2.116 \mathrm{~kg} /$ thn dengan harga jual $\mathrm{Rp}$. $25.000 / \mathrm{kg}$ sehingga rata-rata penerimaan petani ikan sebesar Rp 60.833.334/tahun.

\section{Analisis Pendapatan Budidaya Ikan Mujair Pola Keramba Jaring Apung}

Pendapatan adalah selisih antara besarnya penerimaan dengan biaya yang dikeluarkan sebagai biaya produksi dalam suatu produksi. Besarnya pendapatan yang diterima peternak ikan dapat disajikan pada Tabel 16 dan lampiran 11.

Tabel 16. Rata-rata Pendapatan dari Budidaya Ikan Mujair Pola Keramba Jaring Apung di Kecamatan Warkuk Ranau Selatan

\begin{tabular}{clc}
\hline No & \multicolumn{1}{c}{ Uraian } & Jumlah \\
\hline 1 & Penerimaan & 60.833 .334 \\
2 & (Rp/Tahun) & 35.610 .868 \\
3 & Biaya Produksi & 25.222 .467 \\
& (Rp/Tahun) & \\
& Pendapatan & \\
& (Rp/Tahun) & \\
\hline
\end{tabular}

Sumber :Data primer yang diolah, 2017

Pendapatan pada budidaya ini diperoleh dari hasil pengurangan antara penerimaan dengan biaya total berdasarkan hasil analisis penerimaan ikan mujair sebesar Rp.60.833.334/Tahun dan biaya produksi sebesar Rp.35.610.868/Tahun, maka diperoleh pendapatan sebesar Rp.25.222.467/Tahun.

\section{KESIMPULAN DAN SARAN}

\section{A. Kesimpulan}

Berdasarkan pada hasil penelitian yang telah dilakukan maka dapat ditarik suatu kesimpulan sebagai berikut :

1. Faktor - faktor yang berpengaruh signifikan yaitu luas KJA, pakan, dan bibit terhadap produksi budidaya ikan mujair dan untuk tenaga kerja berpengaruh tidak signifikan terhadap produksi ikan mujair di Desa Kota Batu.

2. Besarnya Pendapatan rata - rata petani budidaya ikan mujair dengan pola keramba jaring apung adalah sebesar Rp.25.222.467/thn

\section{B. Saran}

Berdasarkan hasil penelitian maka penulis akan memberikan saran sebagai bentuk perhatian terhadap penelitian ini dan untuk petani budidaya ikan mujair dengan pola keramba jaring apung adalah sebagai berikut :

1. Disarankan untuk penelitian lanjutan untuk menganalisis batas optimalisasi pendapatan ikan mujair dengan menggunakan variabel tenaga kerja, untuk melihat batas optimalisasi penggunaan tenaga kerja terhadap pendapatan petani ikan.

\section{DAFTAR PUSTAKA}

Abdulkadir, I. $2010 . \quad$ KJA. http://www.farraqafy.com. (diakses 10 September 2017).

Achmad. E. S, 2017. Analisis Faktor Faktor yang Mempengaruhi Produksi Budidaya Ikan Lele (Clariasbatracus)di Kecamatan Buay Madang Timur Kabupaten OKU Timur. Skripsi S1 Universitas Baturaja, Baturaja.

Ahmad, et al. 1991. Potensi Sumberdaya Perikanan dan Prospek Pengembangan. Laporan Akhir. Balitbang. Jakarta.

Anonim, 2011. Budidaya Ternak Ikan Mujair http://blogspot.com. (diakses 23 September 2017). 
Anto,

M.

2015.

BudidayalkanMujairhttp://www.b anyudadi.com. (diakses 12 September 2017)

Ardhya R.E. 2013. Analisis Faktor-Faktor yang Mempengaruhi Produksi dan Pendapatan Usaha Budidaya Ikan Mas Koki. Skripsi Institut Pertanian Bogor. Bogor.

Arief, H. 2015. Analisis Faktor-Faktor yang Mempengaruhi Produksi Usaha Keramba Ikan Mas di Kecamatan Babirik Kabupaten Hulu Sungai Utara

Asmanto, 2011. Budidaya Ikan Dalam Keramba Jaring Apung. http://blogspot.com. (diakses 18 september 2017).

Badan Pusat Statistik. 2014. Berita Resmi Produk Domestik Bruto. Http://www.Bps.Go.Id (diakses 8 November 2017).

Dinas Perikanan dan Kelautan Sumatra Selatan. 2011. Statistik Perikanan Sumatera Selatan. Palembang.

DirektoratJendralPerikananBudidaya 2009.

Perikanan Budidaya. Buku Saku Statistik Perikanan Budidaya Tahun 2008. Jakarta.

Direktorat Jendral Perikanan Budidaya. 2014. Laporan Tahunan Direktorat Produksi Tahun 2013. Direktorat Jendral Perikanan Budidaya. Jakarta.

Elfira, M. 2015. Faktor-Faktor Yang Mempengaruhi Produksi Ikan Lele Dumbo (ClariasGariepinus) di Kenagarian Ladang Kecamatan Tigon Nagari Kabupaten Pasaman.

Fauziah, Antika F. 2015. Analisis Pendapatan dan Permasaran Ikan Mujair di Desa Mojomulyo Kecamatan Puger. Program Studi
Agribisnis Fakultas Pertanian Universitas Jember. Jember.

Ferryanto. 2011. Pengertian Penerimaan Jenis - jenis. http://Ferryanto.blogspot.com. (diakses 5 oktober 2017).

Hermanto. 1989. Ilmu Usaha Tani. PenebarSwadaya. Jakata.

Iswanto, T. 2008. Usaha Pembenihan Ikan Mujair di Kecamatan Cengkaringan Sleman. Skripsi S1.UPN Yogyakarta.

Kartika. J , 2014. Analisis Efisiensi Faktor yang Mempengaruhi Produksi Ikan Koi di Kecamatan Cisaat Kabupaten Sukabumi Provinsi Jawa Barat. Skripsi S1 Institut Pertanian Bogor, Bogor.

Lince. A.S, 2013. Analisis faktor - faktor yang mempengaruhi produksi Ikan nila di kecamatan haranggaol horisan Kabupaten simalungun. Tesis Pascasarjana Universitas Negeri Medan, Medan.

Marjuki, 2002. Pembenihan dan Pembesaran Nila. Penebar Swadaya, Jakarta.

Mukti, 2013. Budidaya Ikan. http:/budidaya-ikan.com. (diakses 19 Oktober 2015).

Natakesuma, I. 2016. Analisis Produksi dan Finansial Usaha Budidaya Ikan lele di Kota Metro. Program Pascasarjana Megister Agribisnis Fakultas Pertanian Universitas Lampung. Bandar Lampung.

Nikijuluw V.P.H., 1992. Tinjauan Ekonomi Budidaya Ikan Keramba Jaring Apung.

Rahim, A dan D.R.D Hastuti. 2007. Ekonometrika Petanian (Pengantar Teori dan Kasus). Penebar Swadaya. Depok. 
Rukmana, R. 2003. Mujair Budidaya dan Pascapanen. Cv. Aneka Ilmu anggota IKAPI. Semarang.

Saputra, 2014.Budidaya Ikan Air Tawar. http//profil saputra.blogspot.com. (diakses 8 November 2017).

Soekartawi, 1993. Resiko dan

Ketidakpastian dalam Agribisnis.

Teori dan Aplikasi. Rajagrafindo

Persada. Jakarta.

Soekartawi. 2003.Teori Ekonomi Produksi dengan Pokok Bahasan Analisis Fungsi Cobb-douglas. PT Raja Grafindo Persada. Jakarta.

Soekartawi. 2006. Analisis Usaha Tani. UI

Press : Jakarta.

Soekartawi, 2006.Analisis Usahatani. Penebar Swadaya. Jakarta.

Soetriono, S. 2012. Pengantar Ilmu Pertanian Umum. Universitas Brawijaya. Malang.

Sukartawi, 1993. Budidaya Laut Dengan Keramba Jaring Apung Mini. Penas VII.

Pertasi Kencana 13-20 Juli, Magelang.

Sulaemann, 2010.Budidaya Ikan Mujair. http//budidayaku.blogspot.com. (diakses 11 November 2017).

Suratiyah, K. 2006. Ilmu Usahatani. Penebar Swadaya. Jakarta.

Susanto, 2008. Status dan Permasalahan Pembenihan Ikan dan Udang di Indonesia http://berita.permasalahanpembenihan-ikan-udang-html. (Di akses 23 september 2017).

Sujono, 2006. Faktor-Faktor Yang Mempengaruhi Produksi Dan Pendapatan

Usaha Mikro Dan kecil. skripsi Institut Pertanian Bogor. Bogor.

UPTD Perikanan, 2015.Kecamatan Warkuk Ranau Selatan Kabpaten OKU Selatan.

Warren, et.all. 2015. PengantarAkuntansi (Edisi 21). Jakarta :SalembaEmpat.

Yuliani, Zaenuddin dan Idris. 2006. Pengaruh Penggunaan FaktorFaktor Produksi Terhadap Produksi Padi Sawah di Kec. Lambuya Kab. Konawe. Universitas Diponegoro. Semarang.

Zahara, N. 2013. Faktor-Faktor Yang Mempengaruhi Produksi dan Pendapatan Padi Organik Di Desa Limansari Kecamatan Buay Madang Timur Kabupaten OKU Timur. Fakultas Pertanian Jurusan Agribisnis Universitas Baturaja. Baturaja. 